\title{
The effect of cultivation technologies on grain and pasta quality of the winter durum wheat varieties
}

\author{
Valentina Likhovidova ${ }^{1,{ }^{*}}$ and Nina Kravchenko ${ }^{1}$ \\ ${ }^{1}$ Agricultural Research Center “Donskoy”, Nauchny Gorodok Str., 3, 347740, Zernograd, Rostov \\ region, Russia
}

\begin{abstract}
The current paper has considered the effect of cultivation technologies of winter durum wheat varieties on their quality indicators through the years with varied weather conditions. The study was carried out in 2015-2019, in the conditions of laboratory and field trials. There have been studied such traits as nature weight, kernel hardness, protein percentage and gluten content of three zoned winter durum wheat varieties sown in weedfree fallow. There has been identified a proportion of the factors' effect on quality indicators. In the curent study there was a range of mean values according to a variety, a year, a cultivation technology. Through the years of study, all variants of technologies contributed to larger grain nature weight, from $768 \mathrm{~g} / 1$ in the variety 'Donchanka' to $792 \mathrm{~g} / 1$ in the variety 'Oniks'. The largest nature weight in the trials was established when using an intensive cultivation technology. Through different years of study, the highest protein percentage in grain was identified in 2016, it was $13.57-17.08 \%$. Through three years, the largest gluten content in grain $(30.06 \%)$ was identified in the variety 'Oniks' when using an intensive cultivation technology. The general assessment of pasta was 4-4.5 points.
\end{abstract}

\section{Introduction}

Winter durum wheat is a highly valuable grain crop, the production of which in the Russian Federation is insufficient to meet the country demand for this raw material. Winter durum wheat is an indispensable source of high quality pasta. It has long been common knowledge that wheat yields and grain quality vary significantly according to genotypes, environmental effects and their correlation, but there is no consensus on which of these factors is more important for most qualitative traits. Some qualitative characteristics are strongly influenced by a genotype, while other traits are more dependent on the environment. Denchich et al. (2011) tested a large group of durum wheat genotypes originating from 28 countries and they recorded high variability in quality among the varieties. The estimation difference was 10 times larger according to different varieties than to the years. The part of the variability in quality is determined by the environment, and nitrogen fertilizing is one of the factors affecting the change in protein percentage and

\footnotetext{
*Corresponding author: valya_17@rambler.ru
} 
composition in grain. Cormier et al. (2013) reported that the interaction between a genotype and nitrogen were significant for yield, grain protein percentage, concentration of $\mathrm{N}$ in straw, the utilization of $\mathrm{N}$ and NUE. Clear understanding of these factors is important to help breeders set the proper goals and strategies for developing durum wheat varieties with specific quality traits to meet the needs of the pasta market and the used automated production facilities (Finlay et al., 2007). Wheat seed buyers should be aware that a particular wheat genotype can produce grain of different quality under different growing conditions.

The researchers have found that there is no correlation between quality and productivity, and there is an opportunity to obtain high yields and good grain quality even under unfavorable year conditions. This fact emphasizes the importance to select the most effective genotypes as an effective measure to improve grain quality, especially under variable and unfavorable conditions.

The quality of pasta is a complex indicator that is determined by many parameters and factors. The products made from durum flour are of higher quality. Pasta is not boiled soft, does not promote putting on weight, it contains more useful microelements. This is due to the different carbohydrate structure of common and durum varieties. Starch in durum wheat has a crystalline form, therefore it does not destroy during milling. Starch in common wheat is amorphous. The properties of pasta, made from common varieties are close to bread.

The main sown area of durum wheat in the country is located in unsuitable conditions for growing this demanding grain crop. The expansion of durum wheat in the zone is hindered primarily by its lower productivity compared to common wheat. This ratio is based on biological and soil-weather factors. The biological ones include the reduced tolerance of durum wheat to air drought and insufficient heat resistance, especially when the generative organs are being formed during the period 'tillering - stem-extension stage'. Therefore, it is necessary to develop varieties with good grain filling and quality in arid conditions.

The purpose of the current study was to identify the effect of varieties and cultivation technologies on the quality indicators of winter durum wheat grain.

\section{Materials and methods}

The study was carried out in the laboratory and field trials in 2015-2019. The objects of the study were two promising zonal winter durum wheat varieties 'Oniks' and 'Lazurit'. The variety 'Donchanka' was used as the standard variety. The trials were conducted in the field of the ABIE DSAU, located in the southern part of the Rostov region. Soil cultivation for winter durum wheat in the trials was carried out according to the "Zonal systems of agriculture of the Rostov region for 2015-2022". The sowing of the studied durum wheat varieties was carried out at the optimum sowing time for the southern zone with a SZ-5.4 seeder with a seeding rate of 400 germinating kernels per $\mathrm{m}^{2}$ in weedfree fallow. In the trial there were studied 4 levels of cultivation technologies were studied (Kiryushin V.I., Ivanov L.A., 2005) according to the following scheme: extensive (control); intensive; conventional; biologized (without mineral fertilizers). There was conducted a two-factor stationary field trial according to the scheme, where Factor A was cultivation technology, Factor B was a variety. The weather conditions during the years of study varied a lot, the year of 2016 was moderately dry, the year of 2017 was optimal, the year of 2018 was severely dry.

The estimation of grain and pasta quality was carried out in the laboratory for biotechnology and grain quality estimation of the FSBSI ARC "Donskoy". At present, the laboratory is working on the study of the physical properties of grain (nature, hardness, 
gluten content and protein percentage), they produce groats, pasta, which, after drying, is studied by its appearance (color, strength and taste).

When estimating grain and pasta quality, there were applied the following GOSTs: GOST 10987-64 (estimation of hardness); GOST - 10840-2017 (nature weight); GOST 10846-91 (protein percentage); GOST - 54478-2011 (gluten content); GOST - 31743-2017 (assessment of pasta quality).

\section{Results and discussion}

The most important indicator of durum wheat grain quality, which characterizes the economic value of the variety, is kernel hardness. Kernel hardness depends on the conditions of the cultivation year to a certain extent. The current study has presented the varied mean values of this trait depending to varieties, years and cultivation technologies. The results ranged from 96 to $99 \%$. In 2016, the average value of kernel hardness of the variety 'Lazurit' was $97.3 \%$ under all four technologies, for the variety 'Oniks' it was 98\%, which was on 0.5 and $1.2 \%$ higher than that of the control variety 'Donchanka'. Having compared the cultivation technologies, the greatest value of kernel hardness was identified when using intensive technology both for the variety 'Lazurit' and 'Oniks'. The mean value of the trait in 2017, under all cultivation technologies, kernel hardness of the variety 'Lazurit' was $96.5 \%$, which was on $0.8 \%$ lower than in 2016 , and the mean value of the variety 'Oniks' was $97.5 \%$, which was on $0.5 \%$ higher its own values of the previous year. In 2018, the mean value of the variety 'Lazurit' was 98.3, and that of the variety 'Oniks' was $97.5 \%$ [8]. Through years of study, the largest value of kernel hardness $(97.8 \%)$ was identified in the variety 'Oniks' and a bit lower (97.5\%) in the variety 'Lazurit' (Table 1).

Table 1. Kernel hardness of winter durum wheat, sown fallow, according to cultivation technology, $\%$.

\begin{tabular}{|c|c|c|c|c|c|}
\hline \multirow{2}{*}{$\begin{array}{l}\text { Technology } \\
\text { (Factor A) }\end{array}$} & \multirow{2}{*}{$\begin{array}{c}\text { Variety (Factor } \\
\text { B) }\end{array}$} & \multicolumn{4}{|c|}{ Kernel hardness, \% } \\
\hline & & 2016 & 2017 & 2018 & Mean \\
\hline \multirow{3}{*}{ Extensive } & Donchaka, st & 97 & 96 & 97 & 97 \\
\hline & Lazurit & 96 & 96 & 98 & 97 \\
\hline & Oniks & 98 & 98 & 98 & 98 \\
\hline \multirow{3}{*}{ Intensive } & Donchaka & 98 & 97 & 96 & 97 \\
\hline & Lazurit & 99 & 98 & 97 & 98 \\
\hline & Oniks & 99 & 97 & 97 & 98 \\
\hline \multirow{3}{*}{ Conventional } & Donchaka & 96 & 96 & 98 & 97 \\
\hline & Lazurit & 98 & 96 & 99 & 98 \\
\hline & Oniks & 98 & 97 & 97 & 97 \\
\hline \multirow{3}{*}{ Biologized } & Donchaka & 96 & 96 & 97 & 96 \\
\hline & Lazurit & 96 & 96 & 99 & 97 \\
\hline & Oniks & 97 & 98 & 98 & 98 \\
\hline \multicolumn{2}{|l|}{$H C P_{05}$} & \multicolumn{4}{|l|}{1.04} \\
\hline \multicolumn{2}{|l|}{$\mathrm{HCP}_{05} \mathrm{~A}$} & \multicolumn{4}{|l|}{0.85} \\
\hline \multicolumn{2}{|l|}{$\mathrm{HCP}_{05} \mathrm{~B}$} & \multicolumn{4}{|l|}{0.73} \\
\hline
\end{tabular}

According to the results of two-factor variance analysis, the main role in the formation of kernel hardness of winter durum wheat varieties sown in weedfree fallow belongs to Factor A of cultivation technology $(36.42 \%)$, repetitions $(31.09 \%)$ and interaction of Factors A and B (33.51\%). The effect of the variety (Factor B) was a bit lower, but at the 
same time it had a sufficient (27.65\%) influence. The proportion of total variation had negative values (-28.67\%) (Figure 1).

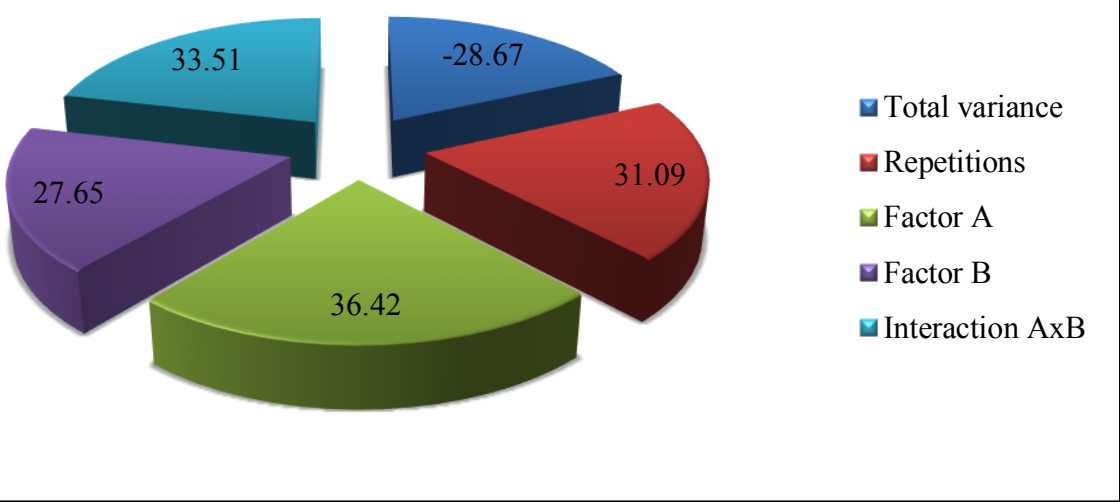

Fig. 1. Proportions of the factors' effect on kernel hardness of the winter durum wheat varieties sown in weedfree fallow.

Nature weight is one of the characteristics that influences upon wheat grain classification in all countries. Nature weight is the ratio of the grain weight to the volume occupied by the grain after free filling into the measuring container. The higher are the indicators of nature weight, the more endosperm is in kernel and the more complete is a kernel. Kernel condition and kernel size affect the groats yield. Durum wheat of the first class, according to GOST, must have a nature weight of at least $770 \mathrm{~g} / \mathrm{l}$. All variants of technology, through the years of study, had a high grain nature weight from 768 (the variety 'Donchanka') to $792 \mathrm{~g} / \mathrm{l}$ (the variety 'Oniks') [8]. The largest nature weight in the experiments was identified when using intensive cultivation technology (Table 2).

Table 2. Nature weight of winter durum wheat, sown fallow, according to cultivation technology, g/l.

\begin{tabular}{|l|l|c|c|c|c|}
\hline \multirow{2}{*}{$\begin{array}{c}\text { Technology } \\
\text { (Factor A) }\end{array}$} & \multirow{2}{*}{ Variety (Factor B) } & \multicolumn{5}{|c|}{ Nature weight, g/l } \\
\cline { 2 - 6 } & & $\mathbf{2 0 1 6}$ & $\mathbf{2 0 1 7}$ & $\mathbf{2 0 1 8}$ & Mean \\
\hline \multirow{3}{*}{ Extensive } & Donchaka, st & 770 & 772 & 775 & 772 \\
\cline { 2 - 6 } & Lazurit & 774 & 776 & 780 & 773 \\
\cline { 2 - 6 } & Oniks & 781 & 783 & 813 & 792 \\
\hline \multirow{3}{*}{ Intensive } & Donchaka & 779 & 781 & 783 & 781 \\
\cline { 2 - 6 } & Lazurit & 786 & 786 & 785 & 786 \\
\cline { 2 - 6 } & Oniks & 790 & 787 & 799 & 792 \\
\hline \multirow{3}{*}{ Biologized } & Donchaka & 778 & 769 & 781 & 776 \\
\cline { 2 - 6 } & Lazurit & 770 & 755 & 780 & 768 \\
\cline { 2 - 6 } & Oniks & 786 & 781 & 786 & 784 \\
\hline$H C P_{05}$ & Donchaka & 767 & 770 & 774 & 770 \\
\cline { 2 - 6 } & Lazurit & 773 & 767 & 777 & 772 \\
\cline { 2 - 6 } & Oniks & 775 & 777 & 786 & 779 \\
\hline$H C P_{05} A$ & 6.01 & 4.91 & & \\
\hline$H C P_{05}$ & 4.25 & \multicolumn{5}{l}{} \\
\hline
\end{tabular}


The conditions of the year influenced the formation of natural weight in the following way, the largest nature weight for all varieties and cultivation technologies was identified in 2016, it was a bit lower in 2017, and significantly reduced in severe dry 2018.

According to the results of two-factor variance analysis, the main role in the formation of nature weight of winter durum wheat varieties sown in weedfree fallow belonged to the proportion of total variance (102.17\%). Factors A and B had no significant effect (5.8 and $11.4 \%$, respectively). The proportion of repetitions and interaction of two factors had negative values, such as -3.37 and $-16.00 \%$, respectively (Figure 2 ).

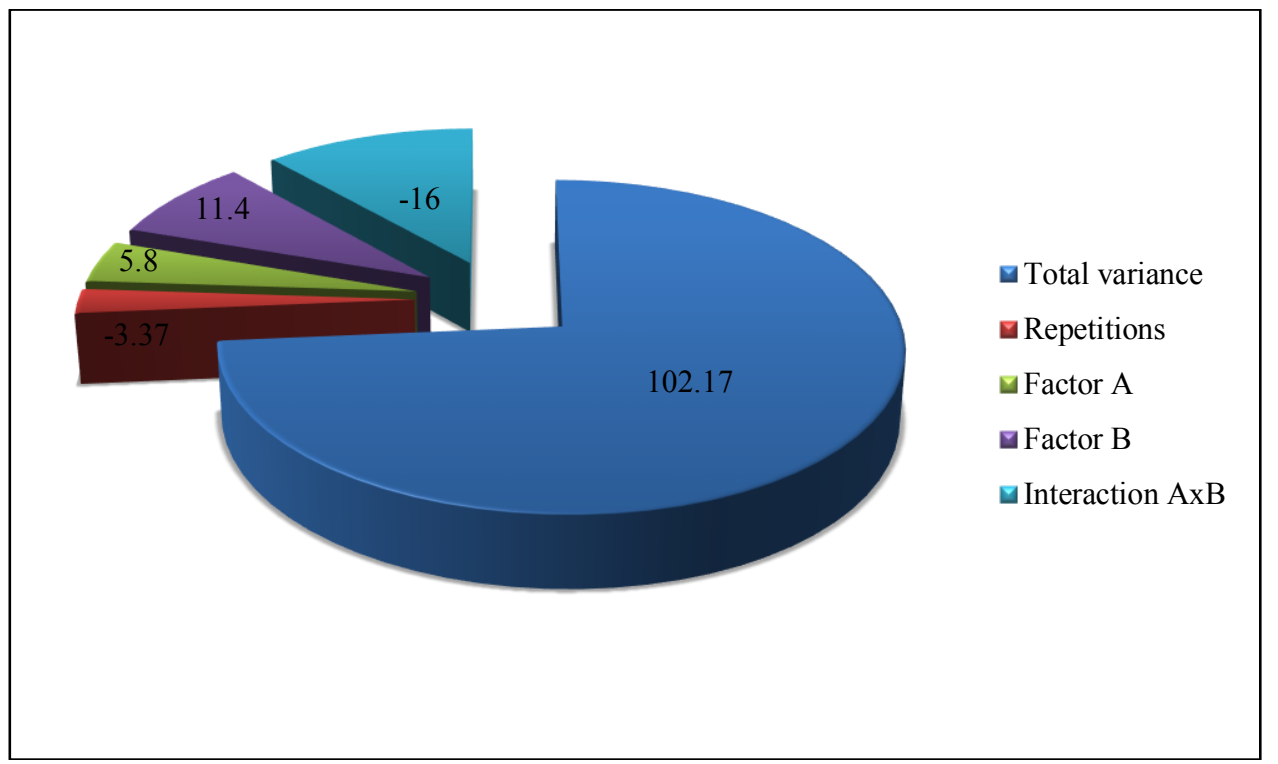

Fig. 2. Proportions of the factors' effect on nature weight of the winter durum wheat varieties sown in weedfree fallow.

The protein percentage in durum wheat grain is not a strictly limiting factor and protein percentage in the range of $12-15 \%$ was quite sufficient to obtain high quality pasta. Through the years of research, its mean percentage in grain of the studied winter durum wheat varieties varied from 13.80 to $17.08 \%$ [8]. Through different years of study, the highest protein percentage in grain was established in 2016, where it averaged $15.9 \%$ across all technologies and varieties (Table 3).

Table 3. Protein percentage in winter durum wheat grain, sown in weedfree fallow, according to cultivation technology, \%.

\begin{tabular}{|c|l|c|c|c|c|}
\hline \multirow{2}{*}{$\begin{array}{c}\text { Technology } \\
\text { (Factor A) }\end{array}$} & Variety (Factor & \multicolumn{4}{|c|}{ Protein, \% } \\
\cline { 2 - 6 } & \multicolumn{1}{|c|}{ B) } & $\mathbf{2 0 1 6}$ & $\mathbf{2 0 1 7}$ & $\mathbf{2 0 1 8}$ & Mean \\
\hline \multirow{3}{*}{ Extensive } & Donchaka, st & 15.13 & 14.1 & 14.16 & 14.5 \\
\cline { 2 - 6 } & Lazurit & 15.32 & 13.80 & 14.12 & 14.41 \\
\cline { 2 - 6 } & Oniks & 16.05 & 15.21 & 15.34 & 15.53 \\
\hline \multirow{3}{*}{ Intensive } & Donchaka & 15.14 & 15.2 & 15.31 & 15.2 \\
\cline { 2 - 6 } & Lazurit & 16.47 & 14.66 & 15.74 & 15.62 \\
\cline { 2 - 6 } & Oniks & 17.08 & 15.83 & 16.22 & 16.38 \\
\hline \multirow{2}{*}{ Biologized } & Donchaka & 15.76 & 15.26 & 15.41 & 15.48 \\
\cline { 2 - 6 } & Lazurit & 16.05 & 14.24 & 15.39 & 15.23 \\
\cline { 2 - 6 } & Oniks & 16.48 & 15.67 & 16.00 & 16.05 \\
\cline { 2 - 6 } & Donchaka & 15.67 & 15.12 & 15.43 & 15.4 \\
\cline { 2 - 6 } & Lazurit & 15.80 & 14.11 & 15.18 & 15.03 \\
\hline
\end{tabular}




\begin{tabular}{|l|l|l|l|l|l|}
\hline & Oniks & 16.17 & 15.47 & 15.71 & 15.78 \\
\hline$H C P_{05}$ & 0.39 & & \\
\hline$H C P_{05} A$ & 0.32 & & \\
\hline$H C P_{05} B$ & 0.28 & \\
\hline
\end{tabular}

The lowest protein percentage of the variety (14.9\%) was established in 2017 . The variety 'Oniks' showed the highest protein percentage with $16.4 \%$ (in 2016), 15.5\% (in 2017 ) and $15.8 \%$ (in 2018) both through the years of study and in each separate year of study among the varieties. According to the results of two-factor variance analysis, the main role in the formation of nature weight of winter durum wheat varieties sown in weedfree fallow belonged to the total variance $(68.5 \%)$. The proportion of repetitions was $16.34 \%$. The effect of Factor B (variety) was $12.42 \%$, and that of Factor A (cultivation technology) was $8.55 \%$. The interaction of two factors had negative values $(-5,81 \%)$ (Figure 3).

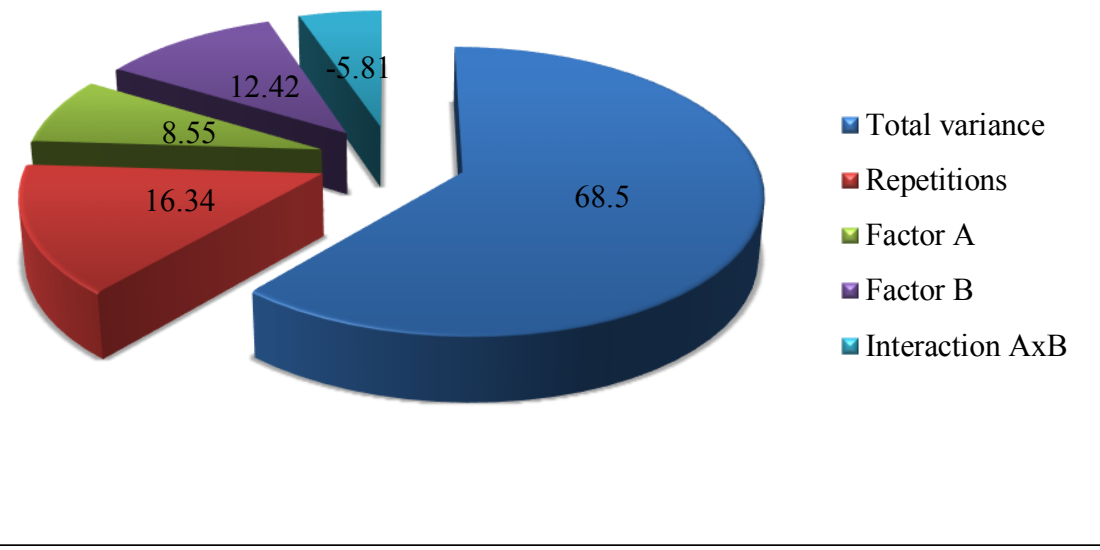

Fig. 3. Proportions of the factors' effect on protein percentage in grain of the winter durum wheat varieties sown in weedfree fallow.

Gluten quality was influenced by the level of the agricultural background, the amount of precipitation, temperature and other vegetation conditions. Through three years, the highest gluten content in grain $(30.06 \%)$ was identified in the variety 'Oniks', when using an intensive cultivation technology (Table 4).

Table 4. Gluten content in grain of the winter durum wheat varieties, sown in weedfree fallow, according to cultivation technology, $\%$.

\begin{tabular}{|l|l|c|c|c|c|}
\hline \multirow{2}{*}{$\begin{array}{c}\text { Technology } \\
\text { (Factor A) }\end{array}$} & \multirow{2}{*}{ Variety (Factor B) } & \multicolumn{4}{|c|}{ Gluten, \% } \\
\cline { 2 - 6 } & & $\mathbf{2 0 1 6}$ & $\mathbf{2 0 1 7}$ & $\mathbf{2 0 1 8}$ & Mean \\
\hline \multirow{3}{*}{ Extensive } & Donchaka, st & 21.1 & 19.8 & 21.8 & 20.9 \\
\cline { 2 - 6 } & Lazurit & 21.9 & 21.2 & 22.3 & 21.80 \\
\cline { 2 - 6 } & Oniks & 23.1 & 20.8 & 22.1 & 22.00 \\
\hline \multirow{3}{*}{ Intensive } & Donchaka & 28.14 & 27.25 & 30.18 & 28.5 \\
\cline { 2 - 6 } & Lazurit & 28.2 & 28.74 & 29.67 & 28.87 \\
\cline { 2 - 6 } & Oniks & 29.24 & 28.87 & 32.08 & 30.06 \\
\hline \multirow{2}{*}{ Biologized } & Donchaka & 25.73 & 23.9 & 24.96 & 24.86 \\
\cline { 2 - 6 } & Lazurit & 26.4 & 24.7 & 24.4 & 25.17 \\
\cline { 2 - 6 } & Oniks & 27.3 & 25.9 & 25.6 & 26.27 \\
\cline { 2 - 6 } & Donchaka & 24.7 & 20.5 & 22.6 & 22.6 \\
\hline & Lazurit & 23.8 & 21.6 & 23.1 & 22.83 \\
\hline
\end{tabular}




\begin{tabular}{|c|c|c|c|c|c|}
\hline & Oniks & 26.7 & 21.8 & 23.0 & 23.83 \\
\hline $\mathrm{HCP}_{05}$ & & 1.2 & & & \\
\hline $\mathrm{HCP}_{05} \mathrm{~A}$ & & 1.0 & & & \\
\hline $\mathrm{HCP}_{05} \mathrm{~B}$ & & 0.87 & & & \\
\hline
\end{tabular}

The most favorable year was moderately arid 2016 with $25.1 \%$ of mean values according to technologies and varieties. According to the results of two-factor variance analysis, the main role in the formation of gluten in grain of the winter durum wheat varieties sown in weedfree fallow belonged to the total variance $(59,57 \%)$ and Factor $\mathrm{A}$ $(48,83 \%)$. The proportion of repetitions had a slight effect $(0.98 \%)$. Factor B and its interaction with Factor A had negative values of -2.82 and $-4.6 \%$, respectively (Figure 4).

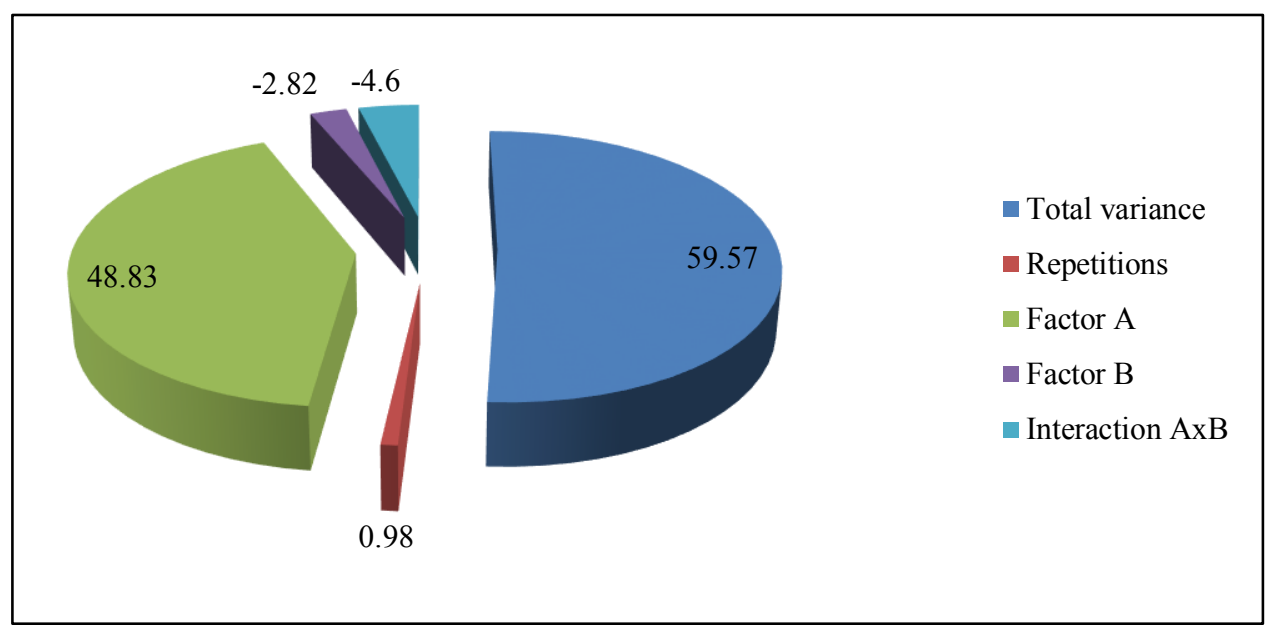

Fig. 4. Proportions of the factors' effect on gluten content in grain of the winter durum wheat varieties sown in weedfree fallow.

The technological properties of pasta directly depended on gluten content and its quality. The estimation of pasta quality was carried out in terms of cooking quality coefficient, in terms of volume and weight, strength, loss of dry matter, color and overall assessment.

The most important quality trait is the color of pasta, which determines their consumer properties. All studied varieties of winter durum wheat had pasta color from yellow to creamy color according to different forecrops and cultivation technologies. The estimation of the indicator varied from 3 to 4 points. The cultivation technology and the forecrop did not affect pasta strength and was quite high in all variants (715-770). Pasta made from all studied varieties had a smooth surface, increased by 3.9-4.0 when cooking and at the same time kept its shape, had a good appearance and taste. The estimation of pasta cooking property by weight and volume was 4.5 points. The general assessment of pasta was 4-4.5 points. These were good indicators of high-quality pasta that could meet all consumer needs.

There has been identified a set of positive correlations among the analyzed traits, that is, protein percentage had a highly positive correlation with nature weight $(r=0.67)$ and a strong correlation with gluten content in grain $(\mathrm{r}=0.66)$. There has been also established a mean correlation between nature weight and gluten content $(\mathrm{r}=0.54)$, between kernel hardness and all quality indicators: protein $(\mathrm{r}=0.39)$, nature weight $(\mathrm{r}=0.53)$, gluten content $(\mathrm{r}=0.37)$. 


\section{Conclusions}

According to the conducted analysis, weather conditions and cultivation technologies had the greatest effect on grain quality of the winter durum wheat varieties. That is why, along with the breeding process, agricultural technologies play an important role in yield quality improvement. The varieties 'Donchanka', 'Lazurit', 'Oniks' have demonstrated high quality of the obtained grain according to all studied traits. The studied varieties had high indicators of grain (1st class) and pasta.

\section{References}

1. A. Alemu, T. Feyissa, T. Letta, B. Abeyo, BMC Genet 21(1), 98-111 (2020)

2. B. Bahar, DUFED 4(1), 1-5 (2015)

3. S. Buranova, J. Cerny, M. Kulhanek, F. Vasak, J. Balik, International Journal of Plant Production 9(2), 257-272 (2015)

4. R.L. Cook, Agronomy Jonznal 108(1), 415-426 (2016)

5. J. Golba, J. Rozbicki, D. Gozdowski, D. Sas, Adjusting yield components under different levels of Napplications in winter wheat

6. H. Grace, C. Keith, M. Charles, S. Minh, The Effect of Organo-Mineral Fertilizer Applications on the Yield of Winter Wheat, Spring Barley, Forage Maize and Grass Cut for Silage (Creative Commons Attribution International License, 2015)

7. M. Hafsi, A. Hadji, A. Guendouz, K. Maamari, Journal of Agronomy 12, 69-77 (2013)

8. M. Khodadadi, H. Dehghani, M.H. Fotokian, B. Rain, J. Bio. Env. Sci. 4(1), 12-23 (2014)

9. V.A. Likhovidova, Agrobiological and physiological bases of the comprehensive evaluation and selection of varieties of winter hard wheat for dry resistance in the south zone of the Rostov region, http://vniirice.ru/dis/lihovidova_dis.pdf

10. Z. Lin, X. Chang, D. Wang, G. Zhao, B. Zhao, Field Crops Research 174, 55-60 (2015)

11. J. Macholdt, B. Honermeier, Yield Stability in Winter Wheat Production (Department of Agronomy, Institute of Agronomy and Plant Breeding I, Germany, 2017)

12. J. Mayer, L. Gunst, P. Mader, M.-F. Samson, M. Carcea, V. Narducci, I. K. Thomsen, D. Dubois, European Journal of Agronomy 65, 27-39 (2015)

13. R. Rusek, Nikos-Szymanska, I. Igros, Bulg. I. Agric. 22, $752-755$ (2016)

14. F. Stefani, S. Dupont, M. Laterrière, R. Knox, Y. Ruan, C. Hamel, M. Hijri, Frontiers in Plant Science 11 (2020) https://doi.org/10.3389/fpls.2020.01206

15. D. Teravest, P.R. Wandschneider, C. Thierfelder, J.P. Reganold, Agricultural Systems 171, 23-35 (2019)

16. W. Xuechun, T. Shishun, H. Mingde, L. Wei, Fujian Academy of Agricultural Sciences Central Laboratory Fuzhou, China, 93 - 106 (2012)

17. Z.C. Yang, N. Zhao, F. Huang, Y.Z. Lu, Soil and Tillage Research 146(30), 47 - 52 (2015) 